\title{
EVALUATION OF COMPOSTING MATERIALS FOR SUSTAINABLE AGRICULTURAL APPLICATIONS
}

\author{
Evlogi Markov, Nikolas Kathijotes, ElenaZlatareva, Svetla Marinova
}

\begin{abstract}
Natural resources are elements of the environment that humans use as a means of production in order to achieve economic development. The aim of the study is based on the evaluation of the proposed 5 natural products /vermiculites, glauconite, straw fly ash, wood biomass and pig manure/ in different proportions to develop various versions of compositions for use in agricultural practice. On the basis of the chemical and agrochemical characteristics of the starting materials, 5 compost samples were prepared from mixing the natural products in a different ratio. These analyzes of the five starting products found, that in vermiculites, glauconite and ash from straw the total amounts of the biogenic element nitrogen and the sum of the mineral fractions of nitrogen (ammonia and nitrate) were very small, whereas for wood biomass and pigs manure the content of the total $\mathrm{N}$ is high. The content of the tested heavy metals is much lower, than the ones defined in the legislation. An exception is made for vermiculite, where the total amounts of chromium and nickel are above the MRLs.

The investigators found, that the $\mathrm{pH}$ in all the mixtures was in the alkaline region, due to the alkaline reaction of the medium with all the starting components. The sum of the mineral fractions of nitrogen for the five mixtures ranges from 163.0 to $241.3 \mathrm{mg} / \mathrm{kg}$. Moving forms of phosphorus and potassium show high values as a result of mixing. No increase in heavy metal values is observed in the different mixtures and the reported values are below the MRLs. The five composts represent a qualitative improver in their use in agricultural practice.
\end{abstract}

Key words: vermiculite, glauconite, straw fly ash, biomass from wood and pig manure

\section{INTRODUCTION}

Mineralogy is a science dealing with minerals, their crystallography, properties, classification, and the ways of distinguishing them.

Minerals make up almost the entirely crust of the earth. They participate in the composition of rocks formations and mineral deposits. Natural resources are elements of the environment that humans use as a means of production in order to achieve economic development.

Based on their characteristics certain products of nature were selected and investigated in this study in terms of their quantity and quality to offer opportunities for their use in agricultural practice in mixtures and at various combinations. These are vermiculites, glauconite, fly ash from straw, wood biomass, and pig manure. Vermiculite is a natural, layered material with a high cation exchange capacity. Thanks to the content of trace elements such as calcium, magnesium, potassium, iron and silicon, vermiculite is a naturally occurring bio stimulant for plant growth. It has been shown to improve the structure and aeration of heavy clay soils and water retention capacity of light sandy soils.

Various studies demonstrate that Vermiculite improves the physical and chemical properties of soils thus increasing their yield (Marinova, et. al., 2012. Mitova, I Marinova, 2012.). Glauconite is known as having an extremely high absorption and cationexchange properties. This is essentially a clay mineral with variable composition, but with a high content of two- and trivalent $\mathrm{Fe}, \mathrm{Ca}, \mathrm{Mg}, \mathrm{K}$ and $\mathrm{P}$, which contain in themselves more than 20 trace elements including $\mathrm{Cu}$, $\mathrm{Ag}, \mathrm{Ni}, \mathrm{Co}, \mathrm{Mn}, \mathrm{Zn}, \mathrm{Mo}, \mathrm{Sb}, \mathrm{Cr}, \mathrm{Be}, \mathrm{Cd}$ and similar ones. Typical to all these elements is that they are very easily found in a recoverable form which is extremely important in agriculture for the production of natural highly easily digestible organic-mineral fertilizers (Yakovleva , Bakalov, 2012). Numerous studies (Postnikov, 1990, Vasilyev, 2009) and research experience testify that glauconite is not only a source of macronutrients $\left(\mathrm{K}_{2} \mathrm{O}\right.$ ranges from $3,7 \%$ to $4,4 \%$, and $\mathrm{P}_{2} \mathrm{O}_{5}$ from $0.41 \%$ to $0.92 \%$ ) as plant food, and above all, a means of improving the soil structure and securing soil moisture.

Manure is a major waste product in animal breeding. Pig manure contains all the nutrients necessary for proper plant growth. Inter macronutrients are introduced into the soil that is, nitrogen, phosphorus, potassium, together with various trace elements such as zinc, copper, nickel, cobalt and molybdenum, enzymes, vitamins, bio stimulants, which are not available in mineral fertilizers and each year are depleted from the soil. With every ton of manure added to the soil, large quantities of organic matter is introduced as humus, which positively influences the soil properties - water permeability, water holding capacity, aeration, etc.

Billions of microorganisms are also imported, which raise soil biogenicity and improve plant nutrition (Lampkin, N., 2002, Marinova, 2013, Sutton et al. 1999).

The combustion of straw from the field crop, the residual product is a small amount of ash, as it can be used as fertilizer on the fields. Plant ash contains mainly potassium, and many other nutrients more important of 
which are phosphors (2-7\%), calcium (from 13 to 30 $60 \%$ ) and also a number of trace elements such as boron, manganese and others. Plant ash has alkaline properties, neutral soil acidity and helps the digestion of nitrogen from humic substances. The supply of this raw material is not a problem.

Ash is freely available in the fields, which usually remains as waste material after harvest and, if not removed, it remains to rot in the fields. Virtually there is not limit of exhaustibility (Nikolova and others. 2010).

Wood biomass is composed of an organic substance synthesized in the process of development of microorganisms, plants and animals. In practice it is used as raw material for bio-energy, and in the preparation of plant compost mixtures (V. Brezin. etc. 2013).

The aim of the study is based on the evaluation of the proposed natural (vermiculites, glauconite, straw fly ash, wood biomass and pig manure) products in order to develop various versions of compositions for use in agricultural practice.

\section{MATERIAL AND METHODS}

The main task was to identify the chemical and agrochemical characteristics of the initial natural products, that is, vermiculites, glauconite, straw fly ash, wood biomass and pig manure.

In order to evaluate their properties, all above materials were analyzed for the following parameters: $\mathrm{pH}$ reaction of the medium, total and moveable form of nitrogen, phosphorus and potassium, calcium, magnesium, cation exchange capacity /ion exchange/ total forms of heavy metals, using the following methods of analysis:

- Reaction to the middle/pH/-BS EN 12176: 2000.

- Solids and water content -BS EN 12880: 2003.

- Total organic carbon - BS EN 13137: 2005.

- Total nitrogen - BS ISO 11261: 2002.

- Mineral nitrogen forms: ammonium /NH4 + -N/ and nitrate /NO3 - N/N - ISO Standard 14255: 2002.

- Moving forms of phosphorus /P/ - BS ISO 11263: 2002.

- Rolling potassium $/ \mathrm{K} /$ - determination is carried out according to the technique of M. Miltcheva used in IPAZR "N. Poushkarov".

- Water-soluble amounts of sulfur /S/ as sulfate /SO4/ - BM-1: 2007.

- Total phosphorus $/ \mathrm{P} /$, potassium $/ \mathrm{K} /$, calcium $/ \mathrm{Ca}$, $\mathrm{Mg} / \mathrm{Mg} /$, heavy metals $-\mathrm{Cd} / \mathrm{Cd}$ chromium $/ \mathrm{Cr} /$, Nikel $/ \mathrm{Ni} /$, copper $/ \mathrm{Cu} /$. Zink $/ \mathrm{Zn} /$, lead $/ \mathrm{Pb} /$, mercury $/ \mathrm{Hg} /$, and arsenic /As/ - BS EN-13346: 2000, BM-1: 2007.

- Electrical conductivity - conductivity meter.

Development of compost variants based on the characteristics of the starting natural product sand vermiculites, glauconite, fly ash from straw, biomass, wood and pig manure.

Based on the results of the chemical and agrochemical evaluation of the initial materials (vermiculites, glauconite, straw fly ash from, wood biomass and pig manure), five mixtures at different ratios for investigations were prepared as below (Table 1):

Table 1. Mixture from different natural products in different ratios, $\mathrm{kg}$

\begin{tabular}{|cccccc|}
\hline Mixture & Vermiculite & Glauconite & Straw ash & Wood biomass & Pig manure \\
\hline I. & 1 & 1 & 1 & 1 & 1 \\
\hline II. & 1 & 2 & 1 & 1 & 2 \\
\hline III. & 1 & 1 & 2 & 1 & 2 \\
\hline VI. & 1 & 1 & 1 & 2 & 1 \\
\hline V. & 1 & 2 & 2 & 1 & 3 \\
\hline
\end{tabular}

\section{RESULTS AND DISCUSSION}

Of all the chemical and agrochemical analyses of the five starting natural product it is found that in vermiculites, glauconite and ash from straw total amounts of the nutrient element nitrogen, are very small, while the woody biomass and pig manure content of total $\mathrm{N}$ is high (Table 1). The same trend continued in the amount of the mineral fractions of nitrogen (ammonia and nitrate). With a maximum content of organic carbon is swine tor- $23.79 \%$, followed by woody biomass- $17.79 \%$. With the low rolling phosphorus are vermiculite and glauconite. The pig manure contains the highest content of rolling phosphorus- $250 \mathrm{P}_{2} \mathrm{O}_{5} \mathrm{mg} / 100 \mathrm{~g}$, followed by wood ash and wood biomass. The three organic raw products incorporating significant amounts rolling potassium, such as in wood ash from the straw it is up to 50 grams per kilogram dry weight. These three products can be good soil improvers, especially for poor potassium soils. The $\mathrm{pH}$ in the entire product is alkaline (from 8.0 to 
10.8).The moisture content is low, except for pig manure. This indicates that the products are in solid state and can be packaged and transported.

The content of examined heavy metals in glauconite, pig manure, wood ash and wood biomass are much lower than those specified in the legislation limits and their introduction into the soil is no risk of contamination with heavy metals. In Vermiculite total quantities of chromium and nickel are above the limit concentrations $/ \mathrm{MAC} /$ according the National legislation.

Table 2. Chemical and agrochemical characterization of the natural source product

\begin{tabular}{|c|c|c|c|c|c|}
\hline Analyses & Vermiculite & Glauconite & $\begin{array}{c}\text { Straw } \\
\text { ash }\end{array}$ & $\begin{array}{c}\text { Wood } \\
\text { biomas }\end{array}$ & $\begin{array}{l}\text { Pig } \\
\text { manure }\end{array}$ \\
\hline $\mathrm{pH}\left(\mathrm{H}_{2} \mathrm{O}\right)$ & 8,6 & 8,0 & 10,8 & 8,5 & 8,0 \\
\hline Moisture \% & 5,74 & 2,30 & 42,07 & 62,65 & 74,38 \\
\hline Organic C \% & 1,58 & 0,67 & 1,76 & 17,79 & 23,79 \\
\hline Total N\% & 0,005 & 0,024 & 0,109 & 1,001 & 1,746 \\
\hline $\mathrm{N}-\mathrm{NO}_{3}+\mathrm{N}-\mathrm{NH}_{4} \mathrm{mg} / \mathrm{kg}$ & 50,1 & 37,4 & 89,3 & 174,5 & 234,4 \\
\hline Subs. $\mathrm{P}_{2} \mathrm{O}_{5} \mathrm{mg} / 100 \mathrm{~g}$ & 0,2 & 1,5 & 194,6 & 116,5 & 250,0 \\
\hline Subs. $\mathrm{K}_{2} \mathrm{O} \mathrm{mg} / 100 \mathrm{~g}$ & 12,3 & 51,0 & 4986,0 & 1637 & 1027 \\
\hline $\mathrm{Cu} \mathrm{mg/kg}$ & 49,5 & 11,5 & 13,0 & 59,5 & 33,5 \\
\hline $\mathrm{Zn} \mathrm{mg/kg}$ & 40,0 & 54,0 & 31,5 & 180,0 & 155,0 \\
\hline $\mathrm{Mn} \mathrm{mg/kg}$ & 310,0 & 159,0 & 215,0 & 335,0 & 240,0 \\
\hline $\mathrm{Cr} \mathrm{mg} / \mathrm{kg}$ & 1215,0 & 42,5 & 4,5 & 12,5 & 4,0 \\
\hline $\mathrm{Ni} \mathrm{mg/kg}$ & 1185,0 & 22,5 & 5,0 & 9,5 & 11,0 \\
\hline $\mathrm{Co} \mathrm{mg/kg}$ & 31,0 & 2,5 & 0,5 & 1,0 & 0,5 \\
\hline $\mathrm{Pb} \mathrm{mg} / \mathrm{kg}$ & 5,0 & 17,5 & 5,0 & 31,0 & 17,5 \\
\hline $\mathrm{Cd} \mathrm{mg/kg}$ & 1,0 & 1,0 & $<1,0$ & $<1,0$ & 1,0 \\
\hline
\end{tabular}

Table 3 presents physical and chemical exchangeable Ca. For other products exchange calcium characteristics of the starting materials. From the data moves in close margins- from 22.5 to $27.6 \mathrm{meq} . / 100 \mathrm{~g}$. presented wood biomass has the highest amounts of The exchange magnesium is most in Vermiculite.

Table 3. Physicochemical parameters of outputs

\begin{tabular}{|c|c|c|c|c|c|}
\hline \multirow{2}{*}{ Products } & $\mathrm{T}_{8,2}$ & $\begin{array}{c}\mathrm{T}_{\mathrm{CA}} \\
\mathrm{T}_{\mathrm{A}}\end{array}$ & $\begin{array}{c}\text { Exch. } \\
\mathrm{Al}\end{array}$ & Exch.Ca & $\begin{array}{c}\text { Exch. } \\
\mathrm{Mg}\end{array}$ \\
\cline { 2 - 6 } & \multicolumn{5}{|c|}{ Meq. / $100 \mathrm{~g}$} \\
\hline Vermiculite & 101,1 & - & 0,0 & 22,5 & 78,6 \\
\hline Glauconite & 27,5 & - & 0,0 & 24,0 & 3,5 \\
\hline Straw ash & 29,5 & - & 0,0 & 26,7 & 2,8 \\
\hline Wood biomass & 88,5 & - & 0,0 & 70,4 & 18,5 \\
\hline Pig manure & 38,6 & - & 0,0 & 27,6 & 11,0 \\
\hline
\end{tabular}

*TCA- Capacity of highly acidic ion exchange

*TA- Capacity of low acid ion exchange 
The higher levels of exchangeable $\mathrm{Ca}$ and $\mathrm{Mg}$ also determine the higher sorption capacity of vermiculite and wood biomass. Thus, submitting them as soil improvers, they will help improve the physicochemical properties of the soil.

Chemical and agrochemical characterization of compost mixtures that ware derived from the vegetation experiments.

Table 4 shows the chemical and agrochemical characterization of the developed mixtures. This data show that the response of the medium at all blends is in the alkaline area, and $\mathrm{pH}$ in water varies in the range from 8.0 to 8.6. This is due to the alkaline reaction medium of all starting components.

The amounts of total nitrogen in I, II and III mixtures appear with similar values. The fourth mixture is found to have the highest content of total nitrogen $0.58 \%$. The amount of mineral fractions of nitrogen for all five mixtures range from 163.0 to $241,3 \mathrm{mg} / \mathrm{kg}$. Mobile forms of phosphorus and potassium show high values as a result of mixing. Mobile potassium in the first two mixtures is 1066 and $1278 \mathrm{mg} / 100 \mathrm{~g}$ respectively, and in the remaining three mixtures it was twice as high. This is beneficial when considering plant nutrition. The organic carbon is highest in the first mixture, with equal participation of the individual components.

There is no increase in the amounts of heavy metals in all mixtures. Although in the initial material of vermiculite higher values of chromium and nickel are detected, as a result of dilution by mixing, the measured values of all heavy metals decrease to non-hazardous concentrations.

Based on the chemical characteristics of the prepared mixtures with different percentages of the parent components, it can be noted that the organic carbon content is highest in mixtures I and V. The total and mobile forms of nitrogen do not vary significantly despite the higher participation of pig manure in a different quantity. Mobile forms of phosphorus and potassium are highest in the fifth mixture that contains a larger amount of pig manure. This is due to the higher content of nutrients in the fertilizer, which is reflected in the admixture.

Table 4. Chemical and agrochemical characterization of the developed mixtures

\begin{tabular}{|l|c|c|c|c|c|}
\hline \multicolumn{1}{|c|}{ Analyses } & Mixture I & Mixture II & Mixture III & Mixture IV & Mixture V \\
\hline $\mathrm{pH}\left(\mathrm{H}_{2} \mathrm{O}\right)$ & 8,5 & 8,0 & 8,6 & 8,6 & 8,2 \\
\hline $\mathrm{pH}(\mathrm{KCl})$ & 8,2 & 7,8 & 8,3 & 8,1 & 7,8 \\
\hline Organic C \% & 12,61 & 4,54 & 6,25 & 8,02 & 10,24 \\
\hline Total N \% & 0,479 & 0,444 & 0,479 & 0,581 & 0,388 \\
\hline $\mathrm{N}-\mathrm{NO}_{3}+\mathrm{N}-\mathrm{NH}_{4} \mathrm{mg} / \mathrm{kg}$ & 241,3 & 163,0 & 220,0 & 211,4 & 222,9 \\
\hline $\mathrm{Subs} . \mathrm{P}_{2} \mathrm{O}_{5} \mathrm{mg} / 100 \mathrm{~g}$ & 185,3 & 211,7 & 215,3 & 192,0 & 237,7 \\
\hline $\mathrm{Subs} . \mathrm{K}_{2} \mathrm{O} \mathrm{mg} / 100 \mathrm{~g}$ & 1066,0 & 1278,0 & 2022,0 & 2201,0 & 2166,0 \\
\hline $\mathrm{Cu} \mathrm{mg} / \mathrm{kg}$ & 32,0 & 22,0 & 38,0 & 41,5 & 26,5 \\
\hline $\mathrm{Zn} \mathrm{mg} / \mathrm{kg}$ & 87,0 & 71,0 & 73,0 & 78,5 & 75,0 \\
\hline $\mathrm{Mn} \mathrm{mg} / \mathrm{kg}$ & 270,0 & 202,0 & 278,0 & 318,0 & 308,0 \\
\hline $\mathrm{Cr} \mathrm{mg} / \mathrm{kg}$ & 114,0 & 66,0 & 142,0 & 137,0 & 98,0 \\
\hline $\mathrm{Ni} \mathrm{mg} / \mathrm{kg}$ & 122,0 & 63,0 & 142,0 & 149,0 & 96,0 \\
\hline $\mathrm{Co} \mathrm{mg} / \mathrm{kg}$ & 8,0 & 6,0 & 10,0 & 11,0 & 7,0 \\
\hline $\mathrm{Pb} \mathrm{mg} / \mathrm{kg}$ & 12,0 & 4,0 & 5,0 & 2,0 & 9,0 \\
\hline $\mathrm{Cd} \mathrm{mg} / \mathrm{kg}$ & 1,0 & 1,0 & 1,0 & 1,0 & 1,0 \\
\hline
\end{tabular}

\section{FINDINGS AND CONCLUSIONS}

1. Of all the chemical and agrochemical analyzes of the five natural products it is found that the response of the soil medium at all tested products was alkaline. In wood biomass and pig manure the content of total and mineral $\mathrm{N}$ is high.
Pig manure contains the highest content of mobile phosphorus - $250 \mathrm{mg} / 100 \mathrm{~g}$, followed by wood ash and wood biomass. The lowest concentration of mobile phosphorus is found in vermiculite and glauconite. The organic carbon in the pig manure has the highest value $23.79 \%$, followed by the wood biomass $-17.79 \%$. 
The three organic feedstocks contain significant amounts of mobile potassium, and in wood ash straw it reaches up to $50 \mathrm{~g} / \mathrm{kg}$ dry weight. These three products can be good soil improvers, especially for poor potassium soils. The moisture content found demonstrates that the products have a solid state and can be safely packaged and carried by a truck.

The content of the studied heavy metals in glauconitic, pig manure, wood ash and wood biomass are much lower than those specified in legislation and their introduction into the soil is not a risk of contamination. An exception is vermiculite, where in the total quantity of chromium and nickel is above the limit concentrations $/ \mathrm{MAC} /$.

From the data on the physicochemical characteristics of the starting materials it is seen that higher amounts of exchangeable $\mathrm{Ca}$ and $\mathrm{Mg}$ appear in wood biomass and Vermiculite. The higher content of exchangeable $\mathrm{Ca}$ and exchanged $\mathrm{Mg}$, determines their higher sorption capacity. Their application as soil improvers will help improve the physicochemical properties of the soil.

2. Based on the characteristics of the starting materials, $\mathrm{V}$ variants with different percentages of the individual components were prepared. The chemical characterization of the compost mixtures found that:

- The reaction medium in any mixtures with the participation of various natural products is in alkaline area- $\mathrm{pH}$ in water varies in the range from 8.0 to 8.6. This is due to the alkaline reaction medium of all starting components.

- The content of total nitrogen in the I, II and III mixtures with similar values. The fourth mixture was distinguished with the highest content of total nitrogen $0.58 \%$. The amount of mineral fractions of nitrogen for all five mixtures ranged from 163.0 to $241.3 \mathrm{mg} / \mathrm{kg}$.

- The Mobile forms of phosphorus and potassium show high values in the result of mixing. The mobile form of potassium in the first two mixtures is 1066 and $1278 \mathrm{mg} / 100 \mathrm{~g}$ respectively, and in the remaining three compositions it was twice as high. This is favorable in terms of the potassium plant nutrition.

- Organic carbon is highest in the first mixture, at the same part of the individual components. An increase in values is observed in the fifth mixture.
- No observed increase in the amounts of heavy metals is registered in various mixtures. The concentration of are below the national tolerance standards (MAC).

- All studies showed that all five mixtures developed, represent valuable and sustainable quality enhancers for use in agricultural practice.

\section{REFERENCES:}

1. Brezin B., Antonov P., Kovatcheva A., 2013, Plant biomass source for the production of biogenic goriva. Izdatelska house in Forestry, Sofia, p.48

2. Postnikov, A. B., 1990, Izpolyzovanie tseolitov in rastinievodstve. Agrochemistry, 7, 113-125 p.

3. Lampkin, N., 2002, Organic farming. Old Pond Publishing, United Kingdom, p.65

4. Marinova, Sv., Toncheva, R., Zlatareva, E., Pchelarova, Hr., Characteristics of vermiculite and its influence on the yield of lettuce in pot experiments. Int. conf. BALWOIS-12, Conf. on Water, Climate and Environment 28.05-2.06. 2012, Ohrid. Proceedings, 713, 2012.

5. Marinova, S., et al., 2013, Manure highly effective means Sutton, A. L., D. Jones, B. Joern, D. Huber,1999, Animal Manure AS a Plant. p. 80

6. Mitova, I., S. Marinova, 2012. Effect of enriched vermiculite the formation of yield and quality in maruli. Pochvoznanie agrochemistry and ecology, god.HL51, from 2.21 to 27

7. Nikolova, S., B. Christov, N. Dimitrova, A., Zhivkova, 2010, Methods in the field of organic farming Handbook, $180 \mathrm{p}$

8. Popandova, St., Zlatareva E., Petkova, E., 2007. Amelioration of solontsovo saline soils with nontraditional materials. Scientific reports. International Scientific Conference "plant gene pool-base of modern agriculture" 13-14.06.2007, Plovdiv, 567-569

9.Vasilyev, AA 2009. Глауконит- Эффективное природное минералное удобрение картофеля. Аграрны весник Урала № 6/60 / 35-37

10.Yakovleva, Elena., A. Bakalov, A., 2012. "Glauconite as a potential new local fertilizer at kuban region' scientific journal KubGAU, No 82 (08), UDC 631.812.11 C. 


\title{
ОЦЕНКА НА МАТЕРИАЛИ ЗА КОМПОСТИРАНЕ ЗА УСТОЙЧИВО СЕЛСКО СТОПАНСТВО
}

\author{
Евлоги Марков, Николас Катиджотес, Елена Златарева, Светла Маринова
}

\begin{abstract}
Резюме. Природните ресурси са елементи на природната среда, които на определен етап от стопанското развитие могат да се използват като средство за производство.

Целта на разработката е въз основа на характеристиката и оценката на природни продукти да се разработят различни варианти от смеси за използването им в практиката- вермикулит, глауконит, пепел от слама, биомаса от дървесина и свински тор. Въз основа на химичната и агрохимична характеристика на изходните материали са изготвени 5 компостни образци получени от смесването на природните продукти в различно съотношение. Химичните и агрохимични анализи на петте изходни продукта установяват, че във вермикулита, глауконита и пепелта от слама общите количества на биогенния елемент азот и сумата от минералните фракции на азота /амониев и нитратен/, са много малки, докато при дървесната биомаса и свинския тор съдържанието на общ $\mathrm{N}$ е високо. Съдържанието на изследваните тежки метали е много по-ниско от определените в законодателството. Изключение прави вермикулитът, където общите количества хром и никел са над пределно допустимите концентрации /ПДК/.

Изследванията установяват, че $\mathrm{pH}$ на всички смеси е в алкалната област, което се дължи на алкалната реакция на средата при всички изходни компоненти. Сумата от минералните фракции на азота за петте смеси се движи в границите от 163,0 до $241,3 \mathrm{mg} / \mathrm{kg}$. Подвижните форми на фосфор и калий показват високи стойности в резултат от смесването. Не се установява завишаване в стойностите на тежки метали в различните смеси и отчетените стойности са под ПДК. Петте компостни смеси представляват качествен подобрител при използването им в земеделската практика.
\end{abstract}

Ключови думи: вермикулит, глауконит, пепел от слама, биомаса от дървесина и свински тор

доц. д-р Евлоги Марков

ИПАЗР „Н. Пушкаров“

София, 1080,ул „Шосе Банкя“ 7

e-mail: evlogy2005@abv.bg

проф. д-р Николас Катиджотес

Университет в Никозия

1700 Никозия, Кипър

e-mail: nkathijotes@gmail.com

доц. д-р Елена Златарева

ИПАЗР „Н. Пушкаров“

София, 1080,ул „Шосе Банкя“ 7

e-mail: zlatareva.as@abv.bg

проф. д-р Светла Маринова

ИПАЗР „Н. Пушкаров“

София, 1080,ул „Шосе Банкя“ 7

e-mail: svetla_mar@mail.bg

\author{
Assoc. Prof. Evlogi Markov \\ ISSAPP "N. Poushkarov" \\ 1080 Sofia, 7 Shosse Bankya str. \\ e-mail: evlogy2005@abv.bg \\ Prof. Nikolas Kathijotes \\ University of Nicosia \\ 1700Nicosia, Cyprus \\ e-mail: nkathijotes@gmail.com
}

Assoc. Prof. Elena Zlatareva

ISSAPP "N. Poushkarov"

1080 Sofia, 7 Shosse Bankya str.

e-mail: zlatareva.as@abv.bg

\section{Prof. Svetla Marinova}

ISSAPP "N. Poushkarov"

1080 Sofia, 7 Shosse Bankya str

e-mail: svetla_mar@mail.bg 